IZVORNI NAUČNI ČLANAK

\author{
Prof. dr Judit Sándor
}

\title{
RIGHT TO HEALTH AND THE HUMAN ORGAN: RIGHT AS A CONSEQUENCE? ${ }^{1}$
}

\begin{abstract}
In this paper I will analyze the right to health and right to health care in a special context, in the field of organ and tissue donation. I will argue that the cases of organ and tissue transplantation provide a useful means for the discussion of the main conceptual challenges to these twin rights. Furthermore the investigation of the scope of these rights in the context of transplantation provide an important aspect to understand to what extent can right to health encompass not only the claim to have access to basic health services but also to what extent non pecuniary solidarity in the form of relying the others' altruism can shape the contours of these rights. For the purposes of concentrating on right to health I will not differentiate between cadaver and living organ donation, only when it is absolutely necessary to make such a distinction. In order to demonstrate how existing European legislation created a special field to right to health, I will start my analysis with exploring the nature and main sources of right to health then I will demonstrate how new fields might be developed, such as the right to health in the context of organ donation.
\end{abstract}

Keywords: right to health, right to health care, allocation of organs, organ donation, transplantation, altruism, scarcity of organs, biomedicine, bioethics, cadaver, Hungarian health law.

\section{Turbulent Historical Retrospect}

When I started to work as a lawyer, just two years before the political transition in Hungary, a very unusual legal trial reached the Supreme Court,

* Professor of law, political science and gender at the Central European University, Budapest, Hungary; Director of the Center for Ethics and Law in Biomedicine e-mail: sandorj@ceu.hu

1 This paper was presented at the $19^{\text {th }}$ Annual Conference on 'The Individual vs. the State' with the title "An Enforceable Right to Health?" at the Central European University, Budapest, June 10-11, 2011. My research on the legal policy of organ transplantation was supported by the FP7-HEALTH-2009-single-stage Coordination Project on Living Organ Donation in Europe (EC-Grant Agreement $n$ 242177). 
that time the Supreme Court of the 'Hungarian People's Republic'. It was the 'hypophysis affair' by its popular name. ${ }^{3}$ A prestigious professor at the University of Szeged, and head of the endocrinology department, Ferenc László conducted a scientific cooperation with the Italian Serono company for some ten years: in exchange for medical products he sent to Italy several thousands of pituitary glands (hypophysis) removed from Hungarian cadaver bodies to use them as raw materials in scientific research. In 1986 the Italian partner was stopped by customs officers at the airport and found the pituitary glands in the bag. This resulted in a more systematic investigation and Prof. László was accused of misappropriation as he exchanged pituitary glands for less value than the authorities expected. It was an embarrassing dimension of the case that the Hungarian state-owned Human Vaccine Substance Production Company was actually engaged in the same type of transaction, and not only collected pituitary glands from Hungarian cadavers but also sent it abroad - and one of the destinations was the Italian Serono company. So the ultimate legal debate at the Supreme Court was not about the misappropriation of the cadaver human brain tissues without the knowledge of the relatives but rather about whether Prof. Lászlós cooperation with Serono was an acceptable and licensed transaction or rather an agreement merely for private financial gains. The defendant, just as the Hungarian state company, argued that their main concern was to offer better health care services for patients in Hungary. Interestingly, patients and the Hungarian public had a very different reaction to this case as this was the first occasion that the public learned about the prevailing opting out system of organ removal. And as autopsies were conducted each time when someone died at a hospital, in theory every Hungarian citizen was a potential organ donor without even knowing about it. Though patients' rights and even attitudes to organ and tissue donation have changed since 1987 the basic dilemmas on how to assess the rights of the donors and recipients remain.

Right to health is a subject of numerous constitutional debates and serves as a main argument in public health reforms. In addition, a number of important international human rights documents have also reaffirmed the right to health. WHO and UNESCO declarations and policy reports were adopted on the subject, the delegates at the 2008 Bamako Global Ministerial Forum in Mali recognized that a world is facing significant

2 The Supreme Court had to deal with the pituitary gland sale case after the defendant submitted appeal against the decision of the Country Court (Csongrád Megyei Bíróság B.468/1986/17). The 'People's Republic' in the official name of a country refers to the political structure directed by a communist party.

3 The Times of London reported on the trial already in 1986. See Boyes, R., Brains for Dollars, The Times, October 10, 1986, reprinted in Urban, G. R., 1988, Social and Economic Rights in the Soviet Bloc, New Brunswick, NJ, Transaction Books, pp. 157-158. 
environmental, demographical, social and economic challenges, therefore the so-called "Bamako Call for Action"4 urged national governments to give priority to the development of policies for research and innovation in the health sector as part of their broader national strategies.

Right to health has been a recurring topic of legal debates ever since its formal recognition as an international human right. Adamantia Pollis argues that there is a marked difference between Western and traditional societies in the recognition of the right to health. "In both traditional and Western societies there is a concept of equality, but its meaning is substantively different. In traditional communities entitlements in terms of power, authority and privileges are differential, dependent on one's status in the communal group but economic and social rights are equal entitlements for all members. Conversely, in Western liberal societies individual civil and political rights are equal entitlements but economic and social rights are differential." ${ }^{5}$ While this sharp opposition between the legal sensitivities and value systems between traditional (purportedly not liberal) and Western (supposedly modern and liberal) societies is problematic, this quote nevertheless calls our attention to the great variety in how the different rights are considered more or less important in the various countries of the world for maintaining a balanced and just society.

There is also an ambiguity when the scope of protection is discussed: what is the difference between referring to a right to health or a right to health care? In the legal literature we can find examples for discussing and promoting both notions, sometimes comparing them, sometimes using them interchangeably. ${ }^{6}$ According to the UNESCO IBC Report on various social determinants of health conditions, "health care has a limited but not negligible role as a determinant of health." 7 Right to health is usually considered as a broader right that includes basic concerns for a

4 The Bamako Call to Action on Research for Health Strengthening research for health, development, and equity from the Global Ministerial Forum on Research for Health Bamako, Mali, November 17-19, 2008.

5 Pollis, A., 1996, Cultural Relativism Revisited: Through a State Prism, Human Rights Quarterly 18, pp. 316-344.

6 Roscam Abbing, H. D. C., 1979, International Organizations in Europe and the Right to Health Care, Deventer, Kluwer; Molinari, P. A., The Right to Health: From the Solemnity of Declarations to the Challenges of Practice, International Digest of Health Legislation, vol. 49, no. 1, special issue: Health Legislation at the Dawn of the 21st Century, 1998, Geneva, World Health Organization,

7 International Bioethics Committee, UNESCO, Preliminary Draft Report of the IBC Working Group on Social Responsibility and Health, Paris, April 18, 2007 (Document No. SHS/EST/CIB-14/07/CONF.507/2, available at unesdoc.unesco.org/ images/0015/001505/150522e.pdf), 13. Last accessed on December 15, 2011. 
healthy environment not just a general access to health care. The broader concept of right to health thus encompasses the availability of clean air and drinking water, access to adequate food and housing, healthy working conditions and safe roads - as all of them may contribute to good health.

The conceptual problem goes as follows. Right to health is understood as a form of social right: a claim to have access to the basic conditions that allow for a healthy life. Furthermore, health is understood as a fundamental precondition to life and to several other rights. People with serious illness or living in environment that is dangerous to their health may not fully participate in active social life, may not be able to work, may not be able to procreate and to raise children, and they may depend on charity or social benefits throughout their life. In other words, a certain standard of health serves as a guarantee to pursue an active, autonomous and independent life. The problem is complex as health is understood as a state determined by psychological, social, cultural, economic, and technical factors. ${ }^{8}$ Therefore, we may find two extreme positions in the legal literature: one that considers right to health as a vague concept that might be listed among the general priorities of the state but does not have a place in the constitutions; and the other considers right to health as a core right that is essential to enjoy other rights.

In this paper I will analyze the right to health and right to health care in a special context, in the field of organ and tissue donation. I will argue that the cases of organ and tissue transplantation provide a useful means for the discussion of the main conceptual challenges to these twin rights. Furthermore the investigation of the scope of these rights in the context of transplantation provide an important aspect to understand to what extent can right to health encompass not only the claim to have access to basic health services but also to what extend non pecuniary solidarity in the form of relying the others' altruism can shape the contours of these rights. For the purposes of concentrating on right to health I will not differentiate between cadaver and living organ donation, only when it is absolutely necessary to make such a distinction. In order to demonstrate how existing European legislation created a special field to right to health, I will start my analysis with exploring the nature and main sources of right to health then I will demonstrate how new fields might be developed, such as the right to health in the context of organ donation.

8 Callender, C. O., Cultural Differences in Living Organ Donation: A Global Perspective, in Gruessner, R. W. G., Benedetti, E. (eds.), 2008, Living Donor Organ Transplantation, New York, McGraw Hill Medical, pp. 6-15. 


\section{Right to Health in Contemporary Human Rights}

The first and until now one of the most influential norms on human rights, the Universal Declaration of Human Rights (UDHR) was adopted on 10 December 1948. Albeit the Declaration is not legally binding, it does encompass almost the entire scope of human rights and fundamental freedoms. ${ }^{9}$ The right to the enjoyment of the highest attainable standard of physical and mental health was first mentioned in an international document two years before it appeared in the UDHR. The preamble of the 1946 Constitution of the World Health Organization (WHO) defined health as "a state of complete physical, mental and social well-being and not merely the absence of disease or infirmity." The preamble further stated that "the enjoyment of the highest attainable standard of health is one of the fundamental rights of every human being without distinction of race, religion, political belief, economic or social condition." ${ }^{10}$

In the Universal Declaration of Human Rights, Article 22 formulated a general basis for social and welfare rights. "Everyone, as a member of society, has the right to social security and is entitled to realization, through national effort and international co-operation, and in accordance with the organization and resources of each State, of the economic, social and cultural rights indispensable for his dignity and the development of his personality." ${ }^{11}$ Furthermore it is clearly reflected in Article 25 that a minimum standard of health is an essential part of social rights. Interestingly, this early international norm provided a legal basis for both the right to health and the right to medical care:

(1) Everyone has the right to a standard of living adequate for the health and well-being of himself and of his family, including food, clothing, housing and medical care and necessary social services, and the right to security in the event of unemployment, sickness, disability, widowhood, old age or other lack of livelihood in circumstances beyond his control (emphasis mine). ${ }^{12}$

In the International Covenant on Economic, Social and Cultural Rights, Article 12, paragraph 1 provides for "the right of everyone to the

9 Adopted and proclaimed by the General Assembly resolution 217 A (III) of 10 December 1948 and Reaffirmed by more then 100 countries which participated the World Conference on Human Rights, held in Vienna in 1993. U.N. Doc. A/CONF. 157/23-4 (Part I) 13 October 1993, para 5.

10 Constitution of the World Health Organization, Official text available at www.who. int/governance/eb/who_constitution_en.pdf.

11 Universal Declaration of Human Rights, Article 22, official text available at www. un.org/en/documents/udhr/index.shtml, November 15, 2014.

12 Universal Declaration of Human Rights, Article 25. 
enjoyment of the highest attainable standard of physical and mental health" and paragraph 2 conceptualizes the measures that should be undertaken by member states in order to achieve "the full realization of this right." 13

One of the most recent formulations of right to health can be found in the Universal Declaration of Bioethics and Human Rights adopted by UNESCO in $2005 .{ }^{14}$ In Article 14 the right to health is stated in the context of social responsibility as follows:

1. The promotion of health and social development for their people is a central purpose of governments that all sectors of society share.

2. Taking into account that the enjoyment of the highest attainable standard of health is one of the fundamental rights of every human being without distinction of race, religion, political belief, economic or social condition, progress in science and technology should advance:

(a) access to quality health care and essential medicines, especially for the health of women and children, because health is essential to life itself and must be considered to be a social and human good;

(b) access to adequate nutrition and water;

(c) improvement of living conditions and the environment;

(d) elimination of the marginalization and the exclusion of persons on the basis of any grounds;

(e) reduction of poverty and illiteracy. ${ }^{15}$

It is not common that a human rights declaration includes a justification and explanation within the official text itself and not in an explanatory memorandum: "because health is essential to life itself and must be considered to be a social and human good." Here, the term 'good' has a connotation that health is not a basic need but rather a kind of commodity. According to the IBC Report on this article, "[c] onsidering health as a universal common good can also commit countries to work toward a more equitable distribution of health resources." 16

13 ICESCR, adopted by the United Nations General Assembly on December 16, 1966; official text available at www2.ohchr.org/english/law/cescr.htm\#art12, May 15, 2014.

14 Universal Declaration of Bioethics and Human Rights, see at portal.unesco.org/en/ ev.php-url_id=31058\&url_do=do_topic\&url_section=201.html, November 15, 2014.

15 Universal Declaration of Bioethics and Human Rights, Article 14 on Social responsibility and health.

16 International Bioethics Committee, UNESCO, Report of the International Bioethics Committee on Social Responsibility and Health, available at unesdoc.unesco.org/ images/0018/001878/187899e.pdf, at 21, November 15, 2014. 
Article 14 of the Declaration should be interpreted especially together with Article 13 on solidarity and co-operation. ${ }^{17}$ It follows from these Articles that the UNESCO Declaration is engaged with the notion of solidarity in the field of right to health and interprets it far beyond the notion of an individual right.

\section{State Obligations to Protect Right to Health}

In his seminal work on Human Rights and Their Limits, Wiktor Osiatyński writes that "[c]onstitutional rights should not exceed the minimum necessary for enabling an individual to meet her basic needs. Rights in excess of this threshold can be granted by a statute and limited later if a democratic society decides to change its priorities." 18 In case of right to health basic needs are frequently changing parallel with the increase of the average life expectancy of the population and the possibilities of medical care. Evidently the access to new technology should be protected by statutory rights, while the core protection of health should remain part of the constitutional rights. In addition to the theoretical limitation it is widely stated that social and economic rights place numerous obligations on states. The framework of the international human rights is not particularly sensitive to the questions of economic aspects of rights. Furthermore the distinction between positive and negative rights seems to be less relevant than in the literature. When the World Health Organization (WHO) provided a detailed assessment of the state obligations to protect right to health it followed a very different logic when it differentiated between various forms of duties imposed on states in order to protect the right to health. ${ }^{19}$ Three major categories have been distinguished a) the obligation to respect; b) the obligation to protect; and c) the obligation to fulfill.

The obligation to respect right to health presupposes a negative right, as it requires the states to refrain from interfering directly or indirectly with the right to health. In reference to our closer topic of transplantation, this obligation involves the duty to respect the altruistic wish of the donors to offer tissues and organs for the needy. As it follows, states should refrain from denying or limiting access to the transplantation services; or from imposing discriminatory practices by limiting the access to transplantation by certain groups.

17 "Solidarity among human beings and international cooperation towards that end are to be encouraged."

18 Osiatyński, W., 2009, Human Rights and Their Limits, Cambridge, Cambridge University Press, p. 141.

19 www.who.int/hhr/activities/Right_to_Health_factsheet31.pdf, December 15, 2011. 
Article 15(2) of the EU Directive on organ donation and transplantation stipulates that "Member States shall ensure that living donors are selected on the basis of their health and medical history, by suitably qualified or trained and competent professionals. Such assessments may provide for the exclusion of persons whose donation could present unacceptable health risks." 20 In sum, safety and the principle of non-discrimination constitute a legitimate restriction on the obligation to respect the right to health.

The second element of duties analyzed by the WHO is the obligation to protect the right to health which includes a more active participation by the state. WHO states many examples how the availability, accessibility, acceptability and quality of health-care should be granted by the state. Following this reasoning, this obligation includes the duty to provide adequate standards for accessibility and availability in the field of transplantation.

The third element of the state obligations includes the duty to fulfill. It dictates that states should adopt appropriate legislative, administrative, budgetary, judicial, promotional and other measures to fully realize the right to health. This has many important practical aspects. There are countries where black market develops because of the lack of official state infrastructure of organ transplantation which makes impossible to many to seek transplantation services within the official health care sector. In the context of transplantation, the EU directive provides even more detailed and specific obligations imposed on the member states. ${ }^{21}$

20 Directive 2010/53/EU of the European Parliament and of the Council of 7 July 2010 on standards of quality and safety of human organs intended for transplantation, in: Official Journal of the European Union, November 15, 2014, 207/14-29, available at eur-lex.europa.eu/LexUriServ/LexUriServ.do?uri=OJ:L:2010:207:0014:0029:EN:PDF, at L 207/22, December 15, 2011.

21 Directive 2010/53/EU of the European Parliament and of the Council of 7 July 2010 on standards of quality and safety of human organs intended for transplantation L 207/19, Article 4 on Framework for quality and safety:

1. Member States shall ensure that a framework for quality and safety is established to cover all stages of the chain from donation to transplantation or disposal, in compliance with the rules laid down in this Directive.

2. The framework for quality and safety shall provide for the adoption and implementation of operating procedures for:

(a) the verification of donor identity;

(b) the verification of the details of the donor's or the donor's family's consent, authorization or absence of any objection, in accordance with the national rules that apply where donation and procurement take place;

(c) the verification of the completion of the organ and donor characterization in accordance with Article 7 and the Annex; 
Right to health is not equal to the right to become and to stay healthy and it is different from - though related to - patients' rights. Many scholars, including constitutional lawyers, consider the right to health and right to health care as ambiguous, hardly definable rights. According to the United Nations Special Rapporteur on the right of everyone to the enjoyment of the highest attainable standard of physical and mental health ${ }^{22}$, right to health consists of global standards generating legal obligations which demand effective mechanisms of accountability. "The combined effect of these three dimensions - standards, obligations and accountability - may result in the empowerment of disadvantaged individuals and communities." 23

The importance of right to health is evident even in those human rights documents where explicit reference to the right to health is missing. In the lack of specific right to health provisions, the right to privacy or right to liberty is evoked to protect some aspects of right to health. ${ }^{24}$ The

(d) the procurement, preservation, packaging and labeling of organs in accordance with Articles 5, 6 and 8;

(e) the transportation of organs in accordance with Article 8;

(f) ensuring traceability, in accordance with Article 10, guaranteeing compliance with the Union and national provisions on the protection of personal data and confidentiality;

(g) the accurate, rapid and verifiable reporting of serious adverse events and reactions in accordance with Article 11(1);

(h) the management of serious adverse events and reactions in accordance with Article 11(2).

The operating procedures referred to in points (f), (g) and (h) shall specify, inter alia, the responsibilities of procurement organizations, European organ exchange organizations and transplantation centers.

3. In addition, the framework for quality and safety shall ensure that the healthcare personnel involved at all stages of the chain from donation to transplantation or disposal are suitably qualified or trained and competent, and shall develop specific training programs for such personnel."

22 http://www.ohchr.org/EN/Issues/Health/Pages/SRRightHealthIndex.aspx, December $15,2011$.

23 International Bioethics Committee, UNESCO, Report of the International Bioethics Committee on Social Responsibility and Health, 22.

24 In the López Ostra v. Spain case (López Ostra v. Spain, ECtHR Application no. 16798/90, Judgement of December 9, 1994, in Strasbourg) the applicant complained about a waste-treatment plant that emitted fumes, noise and strong smells, which made her family living conditions unbearable and caused serious health problems. She alleged that her right to respect for her home had been infringed due to environmental pollution. The Court examined whether national authorities had taken the measures necessary for protecting the applicant's right to respect for her home and private and family life. The Court held that the Spanish State did not succeed in taking adequate steps to secure the applicant's rights under Article 8(1). 
European Convention on Human Rights ${ }^{25}$ does not include provisions on economic and social rights. However, under expanding conceptualization of the individual right to life, in several cases the Court interpreted the right to health care in the framework of 'the right to life. ${ }^{26}$

As an illustration to this claim, in the case of Ternovszky v. Hungary $^{27}$ the applicant stated that her access to home birth was restricted in Hungary. The ECtHR noted that although the applicant was not prevented from giving birth at home, however, the choice of giving birth in one's home would normally entail the involvement of health professionals, an assumption not disputed by the parties. For the Court, "legislation which arguably dissuades such professionals who might otherwise be willing from providing the requisite assistance constitutes an interference with the exercise of the right to respect for private life by prospective mothers such as the applicant. The lack of legal certainty and the threat to health professionals have limited the choices of the applicant considering home delivery. The foregoing considerations are sufficient to enable the Court to find that there has been a violation of Article 8 of the Convention." ${ }^{28}$ We might say that interference with the access to certain type of health care can constitute a violation of privacy. It is especially relevant when there are legislative obstacles to seek for certain types of medical treatment.

Right to health as a specific right has been rarely called in the debates on transplantation but issues of access to transplantation services and to dialysis have been sporadically formulated as a legal debate on constitutional rights. For instance, in 1997, in the case Soobramoney v. Minister of Health (Kwa Zulu-Natal) ${ }^{29}$, the Constitutional Court of South Africa decided against the universal right to dialysis and kidney transplant. A 41-year-old unemployed man who was diabetic with kidney failure was denied dialysis to be paid from public sources: the municipal budget. The high court upheld the policy of the South African Ministry of Health that restricts public support of dialysis to those that were approved for kidney transplant and awaiting the surgery.

25 Convention for the Protection of Human Rights and Fundamental Freedoms, CETS No. 005.

26 Leary, V. A., 1995, Complaint Procedures and the Right to Health, The Review, International Commission of Jurists. Economic, Social and Cultural Rights and the Role of Lawyers. Special Issue. December, no. 55, p. 114.

27 Ternovszky v. Hungary, ECtHR Application no. 67545/09, Judgment of December 14, 2010, in Strasbourg.

28 Ternovszky v. Hungary. 27.

29 Soobramoney $v$ Minister of Health (Kwazulu-Natal) (CCT32/97) [1997] ZACC 17; 1998 (1) SA 765 (CC); 1997 (12) BCLR 1696 (27 November 1997). 
In sum, the interdependence of right to health in connection with other constitutional rights have been observed in several cases across the world. Interestingly, even when a verbatim reference to the right to health is missing, its scope is covered by other rights. This interdependence is based on the recognition that one has to have a right to health (care), because without this one cannot exercise its right to autonomy, liberty, and rights and freedoms. Edmund Pellegrino eloquently put it "to lack health and to need treatment is to be in a diminished state of human existence - a state quite unlike other deprivations which can be borne if one is healthy." 30

Among the binding norms on bioethics, there is a clear reference to right to health in the Oviedo Convention in Article 3: "Parties, taking into account health needs and available resources, shall take appropriate measures with a view to providing, within their jurisdiction, equitable access to health care of appropriate quality." This right however is not specified in the context of specific treatments, such as transplantation.

\section{Transplantation as a Specific Health Care Service}

While so far I concentrated my efforts to explore right to health now I would like to discuss the dynamic elements ${ }^{31}$ of this right in case of new and extraordinary methods of health care such as transplantation. Right to health, just as the right to privacy, develops in parallel with technological advances. While access to clean water and to protection against epidemic illnesses constitute basic elements of this right, it is hard to argue that right to health encompasses the access to the latest inventions of biotechnology, such as memory enhancement by chip-technology in case of Alzheimer disease. Nevertheless, what was a new and expensive technology yesterday may become a generally accessible routine treatment today. Improving health conditions is an essential element of this right.

The first successful living donor transplantation was performed in Boston on December 24, $1954 . .^{32}$ Since the operation was conducted at

30 Pellegrino, E. D., 1999, The Commodification of Medical and Health Care: The Moral Consequences of a Paradigm Shift from a Professional to a Market Ethic, Journal of Medicine of Philosophy, vol. 24, no. 3 (June), pp. 243-266, at 247.

31 Even within the EU law public health is understood as a dynamic concept Article 168 of the Treaty on the Functioning of the European Union states: "Union Action, which shall complement national policies, shall be directed towards improving public health, preventing human illness and diseases, and obviating sources of danger to human health" by "encouraging cooperation between the member states" and "lending support to their action".

32 Cronin, D. C., Siegler, M., Ethical and Legal Issues: The American Perspective, in: Gruessner, R. W. G., Benedetti, E. (eds.), 2008, Living Donor Organ Transplantation, New York, McGraw Hill Medical, p. 17. 
Christmas, a real miracle was expected. One should note that the operation was still very risky at that time and the major legal problem was whether an intervention involving the removal of a kidney from a healthy donor could be justified by the health and life of the recipient. The legal argument was based on balancing the interests between someone's own bodily integrity and the loss of a relative. For example, in the case of transplantation between identical twins, "the loss of a kidney by the donor would be less devastating than the loss of an identical twin sibling. This operation is necessary for the continued good health and well-being of the donor and in performing the operation the surgeons are conferring a benefit upon the donor." 33

Since then organ donation has become a widespread intervention, especially in the developed countries. "As of January 20, 2006, more than 76,000 living donors have been used for transplant in the United States." ${ }^{4}$ Though the technology is still developing one can easily argue that by now organ transplantation has become a routine treatment of several medical conditions, such as kidney failure. In case of these conditions organ transplantation is a life saving treatment. Recent epidemiological data shows that kidney transplant recipients have reduced mortality compared to dialysis patients on the deceased donor waiting list. ${ }^{35}$ So the legal challenge here is that health cannot be protected by affirming the right even by providing resources for transplant facilities as organ transplantation is not possible without the altruistic act of another human being. "The kidney waitlist more than doubled over the past ten years and nearly tripled in the last thirteen years" 36

Concerning the rights of the donor, the first legal difficulty is whether a medical intervention that physically infringes the health of the donor without therapeutic benefit could be authorized at all. In other terms, the benefit of living donation is the most difficult challenge to assess.

Recognition of legal principles, such as consent, traceability ${ }^{37}$ and safety has been manifested in several legal documents. In the field of

33 Cronin, D. C., Siegler, M., 2008.

34 Cronin, D. C., Siegler, M., 2008, p. 16.

35 Wolfe, R. A., Ashby, V. B., Milford, E. L., Ojo, A. O., Ettenger, R. E., Lawrence Y. C. Agodoa, L. Y. C., Held, P. Y., Port, F. K., 1999, Comparison of Mortality in All Patients on Dialysis, Patients on Dialysis Awaiting Transplantation, and Recipients of a First Cadaveric Transplant, New England Journal of Medicine, vol. 341, no. 23 (December 2), pp. 1725-1730.

36 Goodwin, M., 2009, Empires of the Flesh: Tissue and Organ Taboos, Alabama Law Review, vol. 6, no. 5 (Spring), pp. 1219-1248.

37 International Bioethics Committee, UNESCO, Report of the International Bioethics Committee on Social Responsibility and Health. Article 10 "Traceability 1. Member 
organ transplantation, the European Union has adopted several specific legal norms. The two key legal sources are the EU Directive on Organ Donation for Transplantation ${ }^{38}$ and the Additional Protocol to the Convention on Human Rights and Biomedicine, on Transplantation of Organs and Tissues of Human Origin. ${ }^{39}$

As to the main contributions to the legal framework to transplantation I will analyze these documents later. One preliminary remark, however, has to be made here. It is striking that these norms, even the Optional Protocol of the Oviedo Convention, seeks to avoid the reference to concrete rights of the donors and the recipients. They address state parties to respect certain standards of transplantation but they do not constitute specific rights. It evokes professionals, but donors and recipients are mentioned only indirectly. (e.g. Article 4 on "Professional standards" states that "any intervention in the field of organ or tissue transplantation must be carried out in accordance with relevant professional obligations and standards."). Nevertheless, as I will argue later, by stating and reaffirming strong state obligations in the field of transplantation and by excluding private agreements and commercialization in the field, these norms inevitably contributed to a new and developing domain of the right to health.

\section{The Role of Socioeconomic and Biosocial SOLIDARITY}

Right to health - unlike right to life or liberty - is based on the assumption of solidarity between citizens. Therefore, whenever right to health is at stake what is discussed in parliamentary debates is the allocation of resources, taxes, insurance and the organization of the health care, pecuniary matters. But even if the state allows transplantation and concentrates resources, these measures themselves are not sufficient efforts in the lack of available, donated organs. It appears that in the field of transplantation a more 'elementary' form of solidarity plays an important role, a kind of biological solidarity not just a pecuniary one. Here the mere compliance with the right to health is not sufficient; people, the potential donors'

States shall ensure that all organs procured, allocated and transplanted on their territory can be traced from the donor to the recipient and vice versa in order to safeguard the health of donors and recipients."

38 International Bioethics Committee, UNESCO, Report of the International Bioethics Committee on Social Responsibility and Health.

39 The Additional Protocol to the Convention on Human Rights and Biomedicine, on Transplantation of Organs and Tissues of Human Origin, adopted in Strasbourg on January 24, 2002, official text available at http://conventions.coe.int/Treaty/en/Treaties/html/186.htm. 
altruism and concerns are necessary to provide means to access right to health. Even solidarity has at least two meanings in this context: one is the mandatory socioeconomic solidarity of providing resources for health care through paying taxes and the other is a kind of voluntary (or default) biosocial solidarity of transferring organs and tissues between citizens. Thus, a citizen not only makes financial contributions to cover the expenses of health services provided to those who need it but might also offer, for example, his/her own liver during his lifetime or after his death. It is striking that although organ transplantation has become possible as a regular medical service only in the twentieth century, transplantation was seen as an example for altruism already centuries before transplantation became a routine medical practice.

Based on the above stated elements I think the rights with respect of organ transplantation, (and even more in the context of the new technologies of regenerative medicine), pose special challenges to right to health for various reasons. One of the most significant elements is that organs, tissues, stem cells, or umbilical cord blood can serve now as useful, often lifesaving therapeutic tools originated from another human being as a form of biological gift. This form of biological gift as such cannot be requested, cannot be assumed, and as it follows it cannot be claimed. The donors might be regarded as Good Samaritans as even family members would not be automatically considered as donors to their sick relatives. Donation of an organ during someone's lifetime, or even after death, is considered as a special, altruistic gift.

So what is the role of the rights then? If no one can legitimately claim to have organ replacement of his non-functioning kidney, heart, or liver what is the role of referring to this right? The state obligation with respect of these services does include the organization of allocating and providing of organs, and the creation of a good regulative framework of granting access to these forms of treatment. Thus, while I have no entitlement to get one specific kidney as a replacement of my non-functioning kidney, I have an entitlement, without discrimination, to be included on the waiting list or, if I have an altruistic and compatible relative to be operated, to receive the kidney from my relative. Furthermore, this right presupposes a legal system that regulates the fair and non discriminatory access to organs a law that provides conditions, training, and oversight body of the waiting list and the allocation of organs.

Right to health seems not to cover the right to access transplantation, and it does not include entitlements to other private persons' altruism. Still, statistical data on the significant differences in the number of transplantations between the various countries may prompt us to argue that individual altruism and biosocial solidarity could be encouraged by strong 
state responsibility to create an optimally organized infrastructure for transplantation. These duties implicitly refer to the new and developing rights of the donors and recipients. As it follows, rights in respect of transplantation constitute a special challenge to the concept of social rights. The state is responsible for cultivating altruism among its citizens by raising consciousness on the need for organ donation, so creating closer ties among citizens in the form of a biosocial solidarity. Melissa Won puts it very eloquently when she says "...the medical practice of organ transplantation demonstrates the most gracious qualities of generosity and sacrifice, where a decision by a living organ donor or deceased donor's grieving family can mean the differences between a second chance at life or years spent waiting before time runs out." 40

In most of the European countries the state has a monopoly of intermediation on the post-mortem, as well as living organ donations. Whoever is willing to donate has to use the state or a state licensed health institution. Access to human organs on an individual basis is forbidden. Separating donors and recipients serves as a form of protection against organ trade and organ trafficking. In my view, creating this monopoly situation in order to protect donors from exploitation and to prevent desperate recipients of buying organs creates further state obligations as the individual is not in the position to protect her health without the active role of the state in fair allocation of available organs and in case of living donation further guarantees are made to check the emotional relations between donors and recipients.

The main driving force behind connecting the right to health with a call for altruism is the oft-mentioned scarcity of transplantable human organs. Of course, the problem is not really the scarcity of human organs, rather the scarcity of information and infrastructure, transparency and public participation, and thus encouragement for altruistic attitudes. If one looks at the number of transplantation cases, it is evident that where medical infrastructure is more developed there is more transplantation per capita. Medical infrastructure matters a lot in the success of organ transplantation. It may explain why there is such a striking difference between the willingness to become an organ donor in Spain (34.6 donors per one million people) and Romania ( 0.5 per one million).$^{41}$ One should realize that scarcity as such cannot serve as a good ethical argument in

40 Wong, M., 2010, Coverage for Kidneys: The Intersection of Insurance and Organ Transplantation, Connecticut Insurance Law Journal, vol. 16, no. 2 (Spring), pp. 535-571.

41 See also European Commission, Key facts and figures on EU organ donation and transplantation, available at ec.europa.eu/health/ph_threats/human_substance/oc_ organs/docs/fact_figures.pdf, December 15, 2011. 
favor of changing the current prohibition on selling organs and tissues for money. Just like the need for fetal tissue shall not serve in itself as an argument for easing abortion laws or the scarcity of financial resources in the elderly shall not serve in itself as argument for adopting a more liberal euthanasia law, economic considerations cannot overrule ethical ones. In other words, scarcity is a policy problem of allocation and better management of health care while the nature and methods of the consent and the status of the human body are ethical and legal issues.

\section{Legal Limitations to Access Human Organs}

Although organ transplantation requires a sophisticated technology and the rights involved in allocating this medical service seem to be so concrete that they are far beyond the generality of human rights, increasing needs for organs, mainly in developed health care systems, and vulnerability of some other parts of the world create a scene for many important human rights issues, in which right to health plays an important role for both the donor and the recipient. Nancy Scheper-Hughes observes that "the circulation of kidneys follows the established routes of capital, from South to North, from poorer to more affluent bodies, from black and brown bodies to white ones, and from females to males, or from poor males to more affluent males." 42

The intent to avoid exploitation therefore has become the major focus of the organ transplantation rules, at least in Europe. It is believed that state has to be involved in the development of a fair allocation of the available organs and organs shall be donated for altruistic motivation not for money. As it follows in the European legal context the prohibition of financial gain is one of the most relevant restrictions. It is applicable in many fields of health care, including organ transplantation. The principle has been formulated in the Oviedo convention and its optional protocol on transplantation.

The arguments against commercialization are partly based on the status of the human body and its components and follow a kind of 'consequentialist' reasoning that shows (often based on various slippery slope arguments) what would happen if law would allow selling our organs. Still all "despite these ambiguities, system of organ donation around the world have dominated by an altruistic model kept apart from the world of commercial markets." 43

42 Scheper-Hughes, N., Illegal Organ Trade: Global Justice and the Traffic in Human Organs, in: Gruessner, R. W. G., Benedetti, E. (eds.), 2008, Living Donor Organ Transplantation, New York, McGraw Hill Medical, pp. 106-121, at 106.

43 Price, D., 2000, Legal and Ethical Aspects of Organ Donation, Cambridge, Cambridge University Press, p. 479. 
The legal regulation of organ and tissue transplantation has always applied various medico-legal categorizations and distinctions. One of the most relevant distinctions lies between live and cadaver donation. Further distinction is made between the donation of a regenerative and non-regenerative tissue and organ. Blood, semen, bone marrow are regarded as regenerative cells and tissues where the donors do not suffer any harm in case the extraction is done without any complication. The overall prohibition of financial gain applies here as well, except for the reimbursement of some costs related to donation. In case of a non-regenerative organ or tissue, as the risk taken by the donor is significantly higher, it involves a more complex procedure of information and consent. For instance, one kidney may be donated even though it is not regarded as a regenerative organ. This elaborated medical terminology of transplantation resulted in several statutory laws in which emphasis was made on the technical aspects of transplantation rather than on its human rights content.

While these categories are based on a more or less well-defined medical notion, the distinction between altruistic and commercial donation seems to be less precise. If we are considered as embodied subjects then we cannot own our own body. In other words human body and its parts shall not be considered as commodity. In order to ban commercialization and commodification of organs, European law is based on the legal cultivation of altruism. But altruism is a problematic and complex category in itself. It is rarely defined in law, thus it was replaced by a personal relationship, preferably family relationship, between the donor and the recipient. Motivations are hard to investigate and even the nature of relationship may not guarantee or exclude altruistic or commercial motivation. The connotation of donation may vary in different jurisdictions. For instance, in France Dominique Thouvénin argues that the main purpose of gift is to establish an irrevocable transfer from donor to recipient. ${ }^{44}$ Contrary to the French model of gift, the Anglo-Saxon scholars recognize the conditional gift by which donor may enhance his influence.

Still, there is a general problem with the interpretation of altruism. Not because it is a vague and an old-fashioned term but because in a strict legal sense it is impossible to investigate such a complex individual motivation, as the altruistic drive. Law, in general, is not capable of rewarding morally positive human characteristics; it focuses instead on the elimination of evil and wrongdoing. So if there is no social evil - such as the possibility of exploitation, discrimination, or violation of dignity - it is beyond the scope of the law to evaluate if someone's act is altruistic or not.

44 Thouvénin, D., 2002, Autour du don et de la gratuité, Revue générale de droit médical, Numéro special, droit santé, pp. 99-108. 
In addition, one person may care for another in many ways, acting on basis of a mutual concern, for example, which is a relationship not restricted only to the relatives. Many legal systems still presume that only close relatives can donate altruistically but reported cases suggest that close friends may be just as good donors. Furthermore, can we still recognize altruism in the so-called paired donation, when someone can help to his relative by donating his organ to another person whose relative as an exchange can donate an organ to his relative? In other words, could exchange be interpreted as a sign of co-passion or the motivation to return humaneness?

Herman Nys raised the issues of a stronger protection of the potential organ donors in Europe ${ }^{45} \mathrm{He}$ is not the only one who misses a more innovative legal approach in this field. According to Charles B. Blankart, it is insufficient to distribute the available "transplantation capacities" (organs) solely according to neediness, because all individuals have the same right to live. The amount of organs to be distributed is generally dependent on the distribution system. ${ }^{46}$

\section{European Legal Framework: Prohibition of FinANCIAL GAIN}

Reported cases of organ and human trafficking from Moldavia, transplant tourism to South Africa, the Philippines, India, and several other countries in the world urged the Bellagio Task Force ${ }^{47}$ and Organ Watch to discuss human rights issues involved in organ transplantation already in 1995. Therefore it did not come as a surprise that the Convention on Human Rights and Biomedicine ${ }^{48}$ clearly forbids the commercialization of organ trade in Article 21 by saying "The human body and its parts shall not, as such, give rise to financial gain." The convention seems to be based on broad consensus as already 20 countries have ratified it and 14 other countries have signed it without ratification. Interestingly, no country submitted reservation concerning the categorical ban on financial gain. Al-

45 Nys, H., Legal Protection of the Deceased Organ Donor in Europe, in: Exter, A. P. den (ed.) 2010, Human Rights and Biomedicine, Antwerpen, Maklu, pp. 221-235.

46 Blankart, C. B., 2005, Donors without Rights: The Tragedy of Organ Transplantation, paper for the European Public Choice Society Meeting, (Manuscript).

47 Rothman, D. et al., 1997, The Bellagio Task Force Report on Transplantation, Bodily Integrity and the International Traffic in Organs, Transplantation Proceedings, vol. 29, no. 6 (September), pp. 2739-2745.

48 Convention for the Protection of Human Rights and Dignity of the Human Being with regard to the Application of Biology and Medicine: Convention on Human Rights and Biomedicine adopted in Oviedo, April 4, 1997, official text available at http://conventions.coe.int/Treaty/en/Treaties/html/164.htm. 
most all reservations were related to transplantation itself - Croatia ${ }^{49}$, Denmark and Norway made a reservation on the restriction of regenerative tissue donation by minors - and not to the financial gain possibly involved. Even financial incentives would be outlawed under the Oviedo framework. The alternative to the human rights model followed by Europe is increasing incentives for donors. An intermediate solution was developed in the State of Wisconsin, as the Wisconsin Act 119 created a state income tax deduction of up to 10,000 USD for expenses incurred by a living donor for the costs of travel, and even for the lost wages. ${ }^{50}$

In the Explanatory Note of the Convention it is clarified that under Article 21, organs and tissues, including blood, should not be bought or sold or give rise to financial gain for the person from whom they have been removed or for a third party, whether an individual or a corporate entity such as, for example, a hospital. Technical acts (sampling, testing, pasteurization, fractionation, purification, storage, culture, transport, etc.) which are performed on the basis of these items may legitimately give rise to reasonable remuneration. For instance, this article does not prohibit the sale of a medical device incorporating human tissue which has been subjected to a manufacturing process as long as the tissue is not sold as such. Furthermore, Article 21 does not prevent a person from whom an organ or tissue has been taken from receiving compensation which, while not constituting remuneration, compensates that person equitably for expenses incurred or loss of income (for example as a result of hospitalization).

The Additional Protocol on Transplantation of Organs and Tissues of Human Origin ${ }^{51}$ provides further guidance for European legislation. This

49 The Republic of Croatia excludes the limitation within Article 20, paragraph 2, subparagraph ii of the Convention, which exceptionally allows the removal of regenerative tissue from a person who is not able to consent solely when no compatible donor with the ability to consent is available, and the recipient is a brother or a sister of the donor. The limitation does not allow the removal of regenerative tissue (bone marrow) from a minor for the benefit of his/her parent. Such a limitation is not compatible with the Law of the Republic of Croatia in force (The Removal and Transplantation of Human Body Parts Act, published in Official Gazette No. 53 of 1991), which allows the transplantation of regenerative tissue from a minor for the benefit of his/ her parent. The Republic of Croatia hereby protects the vital interests of an underage donor, thereby saving the life of the donor's parent who is of the utmost importance (for the minor). The Republic of Croatia will apply Article 20, paragraph 2, sub-paragraph ii of the Convention, to the effect that the receiver is a parent, a brother or a sister of the donor.

50 Wieckert, S., Sollinger, H. W., Incentives in Western Countries: The Wisconsin Model, in: Gruessner, R. W. G., Benedetti, E. (eds.), 2008, Living Donor Organ Transplantation, New York, McGraw Hill Medical, p. 73.

51 The Additional Protocol to the Convention on Human Rights and Biomedicine, on Transplantation of Organs and Tissues of Human Origin. 
protocol was adopted in 2002 and entered into force in 2006; nine countries are signatories to it and twelve of them have also ratified it. ${ }^{52}$ Following the Oviedo Convention, this protocol also supports the categorical ban but it also makes an attempt to offer a more detailed response to the question of what counts for financial gain. It calls the States Parties to apply measures to promote organ transplantation. As Article 19 states, "Parties shall take all appropriate measures to promote the donation of organs and tissues."

Article 21 reinforces the Oviedo framework of the prohibition of financial gain and clarifies the possibility of some payment for services when stating that " 1 . The human body and its parts shall not, as such, give rise to financial gain or comparable advantage." But it also states that the aforementioned provision shall not prevent payments which do not constitute a financial gain or a comparable advantage, in particular:

- compensation of living donors for loss of earnings and any other justifiable expenses caused by the removal or by the related medical examinations;

- payment of a justifiable fee for legitimate medical or related technical services rendered in connection with transplantation;

- compensation in case of undue damage resulting from the removal of organs or tissues from living persons. ${ }^{53}$

Advertising is not banned as such only if it is accompanied by offering money for the organ: " 2 . Advertising the need for, or availability of, organs or tissues, with a view to offering or seeking financial gain or comparable advantage, shall be prohibited."

Article 22 categorically excludes organ and tissue trafficking. "Organ and tissue trafficking shall be prohibited." In the Explanatory Note to Article 21, prohibition of financial gain is linked to human dignity that is laid down in Article 1 of the Additional Protocol.

Furthermore, the Explanatory Note emphasizes that organs and tissues should not be bought or sold or give rise to direct financial gain for the person from whom they have been removed for a third party. Nor should the person from whom they have been removed, or a third party, gain any other advantage whatsoever comparable to a financial gain such as benefits in kind or promotion for example. A third party involved in the transplant process such as a health professional or a tissue bank may not make a profit from organs or tissues or any products developed from

52 On the $1^{\text {st }}$ of December, 2014.

53 Supra note 53. 
them. This latter condition seems to make a distinction between financial gain and profit. In case of third parties, such as health professionals not financial gain but profit gain is prohibited. Needless to say that it is hard to interpret profit once for instance tissue procurement occurs in a private sector for instance if organ removal is linked with a biotechnological invention etc.

However, Article 21 states that certain payments that a donor may receive are not to be treated as financial gain within the meaning of this article. Essentially, apart from the last indent, these provide examples of expenses that may be incurred during or as a result of donation or other parts of the transplant process. This paragraph does not make exceptions to the principle laid down but gives examples of compensation to avoid possible financial disadvantage which may otherwise occur. In the case of the donor it allows for compensation for loss of earnings and other justifiable expenses. ${ }^{54}$

Looking at global and albeit not binding sources, two declarations have to be mentioned. The Universal Declaration on Bioethics and Human Rights adopted by the General Conference of UNESCO in $2005^{55}$ does not provide specific rules for transplantation. Nevertheless, Article 13 of the Declaration emphasizes solidarity and cooperation, Article 14 social responsibility and health and Article 15 the sharing of benefits.

It is hard to tell what the ideal legal model for transplantation is. It should take into account solidarity, religion, tradition, legal culture, history and trust to medical services.

Obviously in the U.S. right to health care would not be called in case of misallocation or discriminatory allocation of organs. Still the issue whether a patient has an entitlement to a specific organ offered to him has reached the Court. In Colavito v. N.Y. Organ Donor Network ${ }^{56}$, the New York Court of Appeals had to answer a question, whether the intended recipient of an organ donation could bring a private cause of action for common law conversion or under the New York Public Health Law if he does not receive the organ. ${ }^{57}$

54 The latest document of the Council of Europe Convention against Trafficking in $\mathrm{Hu}-$ man Organs will be open for signature on 25 March 2015. The Convention has been adopted by the Committee of Ministers on 9 July 2014.

55 Supra note 13.

56 Colavito v. N.Y. Organ Donor Network, Inc., 8 N.Y.3d 43, 58, 860 N.E.2d 713, 722-23, 827 N.Y.S.2d 96, 105-06 (2006).

57 Robert Colavito suffered from serious kidney disease, and he was the intended recipient of two kidneys from the body of his late friend, Peter Lucia. The New York Organ Donor Network sent one of Lucia's kidneys to Florida, where Colavito resided. But 
This case shows the weaknesses of the close donor-recipient team, the mere agreement does not constitute an entitlement to one particular organ. As it was in the case, it could be that even despite benevolent wish the organ may not be suitable for the agreed recipient. On the other hand studies show that states should stimulate the discussion on organ donation so that more people and relatives will support it when a difficult moment of the decision comes.

A Special Eurobarometer Survey, conducted in 2009 across Europe, showed the strongest support for organ donation after death in Sweden (83\%), while high levels are recorded in Finland and Belgium (both 72\%) and Denmark (70\%). It is striking that the weakest support was measured in some of the Central and Eastern European countries, such as Latvia and Romania. ${ }^{58}$

Fear of organ scarcity dominated the discourse both of transplant networks, as well as of the legislators. Therefore the European Parliament adopted a resolution on April 22, 2008 and asked Member States "to remove, before January 2010, legislation that reserves donor organs for use solely within that Member State."

What was the past for some countries is often the recommended new model for the others. For instance, Thedore Silver ${ }^{59}$ in the United States advocated for the post mortem organ draft model as a good solution for dealing with the scarcity of available organs. According to him, “... subject only to exemption for religious objection, the organ draft would empower the state to conscript every cadaver organ suitable for transplantation without regard to any contrary wishes expressed by the decedent while he lived or by surviving relatives after he dies."

According to Theodore Silver, under the American model, this solution would most likely survive the judicial review even if the Court were

contrary to the wishes of the Lucia family, the NYODN allocated the other kidney for another recipient before it was known whether the first one could be successfully transplanted to Colavito. When Colavito's doctor discovered that the kidney sent to Florida was damaged, he tried to obtain the second Lucia kidney from NYODN. That one, however, was by then in the process of being implanted in the other patient. Colavito, thinking that he had an enforceable right to the second kidney, brought suit against the defendants for fraud, conversion, and violation of New York Public Health Law in the United States District Court for the Eastern District of New York. Colavito died between the two court decisions.

58 European Commission Special Eurobarometer Survey 333a (Wave 72.3) on Organ Donation and Transplantation (Brussels: European Commission, 2010). The text of report is available at ec.europa.eu/public_opinion/archives/ebs/ebs_333a_en.pdf, December 15, 2011.

59 Silver, T., 1988, The Case for a Post-Mortem Organ Draft and a Proposed Model Organ Draft Act, Boston University Law Review, vol. 68, no, 4 (July), pp. 681-728. 
to conclude that an individual's decision regarding the disposition of her dead body is protected by the right of privacy. Organ draft constitutes a state interest of sufficient importance to warrant an intrusion into constitutionally protected decision-making.

\section{Conclusions}

In the field of health care, right to health care requires a progressive interpretation whenever a new medical technology promises the preservation of life and health. Progressive interpretation takes into account both the legal and the technological development and though gradually but it enhances and specifies the scope of the rights vis-à-vis the treatments that have become part of the mainstream. The field of transplantation makes it possible to study all classical and new elements of right to health. The European approach, which categorically bans the payment for organs but relies on an opting out system in the case of cadaver donation, created a new public domain in which right to health and right to health care have become essential in the field of transplantation. People on the waiting list for organs evidently have a right to health. But this right does not provide direct entitlement to any particular human organ but it includes access to adequate health care and information with respect to organ donation. Furthermore, fair allocation of available organs, equity, access to postoperative treatment for both the donor and for the recipient are involved in a general right to health. The problem, however, as we have seen, is that the most important element of their health care: the availability of a viable organ depends on the altruism of others. The legal system, and more specifically the constitutional framework, cannot grant access to human organs as part of the basic rights.

So what can we learn from such controversies in the field of organ transplantation? Right to health is not automatically applicable in this context. Right to health has become relevant gradually; in other words, it was a consequence of technical and legal development, rather than a sui generis case for right to health. In order to claim right to health in the field of transplantation it was necessary that transplantation has become a mainstream treatment for several serious, life-threatening illnesses. In comparison, certain new technologies, such as stem cell treatment have not yet reached the stage that they can be considered as reasonably safe, effective and affordable alternatives to transplantation, therefore here one cannot think of equal and fair distribution of goods and access to health. Furthermore, the European legal solution for organ scarcity itself created 
a new and strong State monopoly and obligation to achieve fair and impartial access and allocation of human organs. Alternative solutions were discarded, such as the direct, contract-like relationship between the donor and the recipient, or the market model. So what remains is a new right within the right to health, a right to access to transplantation, a right that has been developed as a consequence of allocating organs in the public domain.

International human rights norms, and even special norms on bioethics, such as the Oviedo Convention, its Additional Protocol, and the nonbinding UNESCO Declarations all engaged with a non-commercial and state governed organ allocation. In 2010 the European Directive on standards of quality and safety of human organs intended for transplantation (Directive on organ donation and transplantation) even further strengthened this by setting standards that would facilitate the exchange of organs to the benefit of thousands of European patients in need of this type of therapy each year.

All these regulative efforts aimed to separate the ones who need organs from those who may donate after the death or in life. They did it so with the aim to protect potential donors and their families from exploitation and from risking their health in case of illegal living donation. Most legal norms aim - perhaps paternalistically - to protect also the recipients from actively searching for available organs. But it follows from the technically and socially created scarcity that the state has entered into this domain and from its duties and monopolies it also follows that donors and recipients can claim rights in this field. The constitutional framework nevertheless may facilitate individual autonomy and the altruism as this framework empowers donors and recipients with the representation of organ transplantation as a public goal that can save lives. The so far unexplored but increasingly developing right to health in this particular context may contribute to a better international and national allocation of available organs by minimizing the dangers of exploitation and by enhancing the rights of the potential donors and recipients who often acted in a legal vacuum situation, passively waiting for charity or those who sought short cut solutions via organ tourism or soliciting for organs could found themselves easily in illegal organ trade and organ trafficking. Right to health as it has developed in the field of several old-new technologies, such as reproduction and genetic services, should be applicable in the field of transplantation, as well. Extension of right to health in order to enhance basic rights of donors and recipients would acknowledge transplantation as an essential treatment and, more importantly, it would value the charity of the organ donors as a contribution to achieve a basic human right. 


\section{BIBLIOGRAPHY}

1. Blankart, C. B., 2005, Donors without Rights: The Tragedy of Organ Transplantation, paper for the European Public Choice Society Meeting (Manuscript).

2. Boyes, R., 1986, Brains for Dollars, The Times, October 10, 1986. Reprinted in George R. Urban, Social and Economic Rights in the Soviet Bloc, New Brunswick, NJ, Transaction Books.

3. Callender, C. O., Cultural Differences in Living Organ Donation: A Global Perspective, in:. Gruessner R. W. G., Benedetti, E. (eds.), 2008, Living Donor Organ Transplantation. New York, McGraw Hill Medical.

4. Cronin, D. C., Siegler, M., Ethical and Legal Issues: The American Perspective, in: Gruessner R. W. G., Benedetti, E. (eds.), 2008, Living Donor Organ Transplantation, New York, McGraw Hill Medical.

5. Exter, A. P. den, 2002, Health Care Law-Making in Central and Eastern Europe. Antwerp, Intersentia.

6. Exter, A. P. den, Hermans, H. (eds.), 1999, The Rights to Health Care in Several European Countries, The Hague, Kluwer Law International.

7. Goodwin, M., 2009, Empires of the Flesh: Tissue and Organ Taboos, Alabama Law Review, vol. 6, no. 5 (Spring).

8. Leary, V. A., 1995, Complaint Procedures and the Right to Health, The Review, International Commission of Jurists. Economic, Social and Cultural Rights and the Role of Lawyers. Special Issue, no. 55 (December).

9. Molinari, P. A., 1998, The Right to Health: From the Solemnity of Declarations to the Challenges of Practice, International Digest of Health Legislation, vol. 49, no. 1, special issue: Health Legislation at the Dawn of the $21^{\text {st }}$ Century, Geneva: World Health Organization.

10. Nys, H., Legal Protection of the Deceased Organ Donor in Europe, in:. Exter, A. P. den (ed.) Human Rights and Biomedicine, Antwerpen, Maklu.

11. Osiatyński, W., 2009, Human Rights and Their Limits, Cambridge, Cambridge University Press.

12. Pellegrino, E. D., 1999, The Commodification of Medical and Health Care: The Moral Consequences of a Paradigm Shift from a Professional to a Market Ethic, Journal of Medicine of Philosophy, vol. 24, no. 3 (June).

13. Pollis, A., 1996, Cultural Relativism Revisited: Through a State Prism, Human Rights Quarterly, 18.

14. Price, D., 2000, Legal and Ethical Aspects of Organ Donation, Cambridge, Cambridge University Press.

15. Roscam Abbing, H. D. C., 1979, International Organizations in Europe and the Right to Health Care, Deventer, Kluwer.

16. Rothman, D. et al., 1997, The Bellagio Task Force Report on Transplantation, Bodily Integrity and the International Traffic in Organs, Transplantation Proceedings, vol. 29, no. 6 (September).

17. Scheper-Hughes, N., 2008, Illegal Organ Trade: Global Justice and the Traffic in Human Organs, in Gruessner, R. W. G., Benedetti, E. (eds.), Living Donor Organ Transplantation, New York, McGraw Hill Medical. 
18. Shakarishvili, G., 2005, Decentralization in Healthcare: Analyses and Experiences in Central and Eastern Europe in the 1990s, Budapest, Open Society Institute.

19. Silver, T., 1988, The Case for a Post-Mortem Organ Draft and a Proposed Model Organ Draft Act, Boston University Law Review, vol. 68, no. 4 (July).

20. Thouvénin, D., 2002, Autour du don et de la gratuité, Revue générale de droit médical, Numéro special, droit santé.

21. Wolfe, R. A., Ashby, V. B., Milford, E. L., Ojo, A. O., Ettenger, R. E., Agodoa, L. Y. C., Held, P. J., Port F. K., 1999, Comparison of Mortality in All Patients on Dialysis, Patients on Dialysis Awaiting Transplantation, and Recipients of a First Cadaveric Transplant, New England Journal of Medicine, vol. 341, no. 23 (December 2).

22. Wong, M., 2010 Coverage for Kidneys: The Intersection of Insurance and Organ Transplantation, Connecticut Insurance Law Journal, vol. 16, no. 2 (Spring).

\section{Legal Documents}

1. Constitution of the World Health Organization. Official text available at www. who.int/governance/eb/who_constitution_en.pdf

2. Universal Declaration of Human Rights (UDHR). Official text available at www. un.org/en/documents/udhr/index.shtml

3. International Covenant on Economic, Social and Cultural Rights (ICESCR), adopted by the United Nations General Assembly on December 16, 1966. Official text available at www2.ohchr.org/english/law/cescr.htm

4. UNESCO Universal Declaration of Bioethics and Human Rights. Official text available at portal.unesco.org/en/ev.php-url_id=31058\&url_do=do_topic\&url_ section=201.html

5. UNESCO, Report of the International Bioethics Committee on Social Responsibility and Health. Available at unesdoc.unesco.org/images/0018/001878/187899e.pdf

6. International Bioethics Committee, UNESCO, Preliminary Draft Report of the IBC Working Group on Social Responsibility and Health, Paris, April 18, 2007 (Document No. SHS/EST/CIB-14/07/CONF.507/2. Official text available at unesdoc. unesco.org/images/0015/001505/150522e.pdf).

7. Convention for the Protection of Human Rights and Dignity of the Human Being with regard to the Application of Biology and Medicine: Convention on Human Rights and Biomedicine adopted in Oviedo, April 4, 1997. Official text available at http://conventions.coe.int/Treaty/en/Treaties/html/164.htm.

8. The Additional Protocol to the Convention on Human Rights and Biomedicine, on Transplantation of Organs and Tissues of Human Origin, adopted in Strasbourg on January 24, 2002. Official text available at http://conventions.coe.int/ Treaty/en/Treaties/html/186.htm

9. Directive 2010/53/EU of the European Parliament and of the Council of 7 July 2010 on standards of quality and safety of human organs intended for transplantation, Official Journal of the European Union, August 6, 2011, L 207/14-29. Official text available at eur-lex.europa.eu/LexUriServ/LexUriServ.do?uri=OJ:L:2010: 207:0014:0029:EN:PDF. 
10. European Commission, Key Facts and Figures on EU Organ Donation and Transplantation. Available at ec.europa.eu/health/ph_threats/human_substance/oc_ organs/docs/fact_figures.pdf

11. European Commission Special Eurobarometer Survey 333a (Wave 72.3) on Organ Donation and Transplantation (Brussels: European Commission, 2010). Official text of the report is available at ec.europa.eu/public_opinion/archives/ebs/ ebs_333a_en.pdf.

Cases

1. López Ostra v. Spain, ECtHR Application no. 16798/90, Judgement of December 9, 1994, in Strasbourg.

2. Ternovszky v. Hungary, ECtHR Application no. 67545/09, Judgment of December 14, 2010, in Strasbourg.

3. Soobramoney v. Minister of Health (Kwazulu-Natal) (CCT32/97) [1997] ZACC 17; 1998 (1) SA 765 (CC); 1997 (12) BCLR 1696 (27 November 1997).

4. Colavito v. N.Y. Organ Donor Network, Inc., 8 N.Y.3d 43, 58, 860 N.E.2d 713, 72223, 827 N.Y.S.2d 96, 105-06 (2006).

\title{
PRAVO NA ZDRAVLJE I LJUDSKI ORGAN: PRAVO KAO POSLEDICA?
}

\author{
Judit Sándor
}

\section{REZIME}

U ovom radu autorka analizira pravo na zdravlje i pravo na zdravstvenu zaštitu u posebnom kontekstu, u kontekstu donacije tkiva i organa. Autorka tvrdi da transplantacija organa i tkiva predstavlja koristan primer za diskusiju o glavnim koncepcijskim izazovima kojima su izložena pomenuta, inače bliska prava. Štaviše, proučavanje obima ovih prava u kontekstu transplantacije pruža značajan ključ za razumevanje do koje mere pravo na zdravlje obuhvata ne samo pravo na pristup osnovnim zdravstvenim uslugama, nego i za to do koje mere nematerijalna solidarnost, u formi oslanjanja na altruizam drugih, može da oblikuje konture navedenih prava.

Od kada je formalno priznato kao međunarodno ljudsko pravo, pravo na zdravlje ne prestaje da bude predmet pravnih rasprava. Kada je reč o pravu na zdravstvenu zaštitu, ono zahteva progresivno tumačenje uvek kada nova medicinska tehnologija obeća očuvanje života i zdravlja. Evropski pristup, koji kategorično zabranjuje plaćeno doniranje, oslanjajući se, istovremeno, uglavnom na sistem pretpostavljene saglasnosti u slučajevima uzimanja organa od umrlog, formirao je novi javni domen u kojem su 
pravo na zdravlje i pravo na zdravstvenu zaštitu postali ključni elementi u postupku transplantacije.

Očigledno je da osobe koje se nalaze na listama čekanja organa uživaju pravo na zdravlje. Međutim, ovo pravo ne obezbeđuje direktno pravo na neki određeni organ, već uključuje pravo na adekvatan pristup zdravstvenoj zaštiti i pravo na informacije u odnosu na donaciju organa. Štaviše, pravična dodela dostupnih organa, pravičnost, kao i pristup donora i primaoca post-operativnim tretmanima, uključeni su u obim opšteg prava na zdravlje. Problem, kao što smo videli, predstavlja najvažniji element zdravstvene zaštite primaoca: naime dostupnost odgovarajućih organa zavisi od altruizma drugih. Pravnim sistemom, tačnije, ustavnim sistemom, ne može se garantovati pristup ljudskim organima u formi osnovnih prava.

Kako autorka pokazuje, pravo na zdravlje ne uključuje pravo da se postane i ostane zdrav, i razlikuje se od prava koja uživaju pacijenti, iako je sa njima povezano. Na prvi pogled izgleda da pravo na zdravlje ne obuhvata ni pravo na pristup transplantaciji. Međutim, statistički podaci o broju izvršenih transplantacija $u$ različitim zemljama mogu nas navesti da tvrdimo da individualni altruizam i biosocijalna solidarnost mogu da budu podstaknuti pojačanom obavezom države da stvori optimalnu infrastrukturu za transplantaciju. Ova nova obaveza implicitno se odnosi i na nova prava donora i primaoca organa, kao i na njihova prava koja se tek razvijaju. Sledstveno tome, prava u vezi sa transplantacijom predstavljaju poseban izazov konceptu socijalnih prava. Država postaje odgovorna za podsticanje altruizma među građanima i to jačanjem svesti o potrebi donacije organa.

Kakva se pouka može izvući iz kontroverze koju prati transplantacija organa? Prvo, pravo na zdravlje nije automatski primenjivo u ovoj oblasti, već ono postepeno dobija na važnosti. Drugim rečima, ono je više posledica tehničkog i pravnog razvoja, nego što je sui generis pravo. Drugo, da bi se moglo tvrditi da je pravo na zdravlje primenjivo u oblasti transplantacije, bilo je potrebno da transplantacija postane glavni tretman u odnosu na nekoliko ozbiljnih bolesti koje ugrožavaju život. U poređenju sa tim, treba primetiti da se neke nove tehnologije, kao što je, na primer, lečenje matičnim ćelijama, još nisu dovoljno razvile da bi se za njih moglo reći da su u razumnoj meri bezbedne, efikasne i pristupačne alternative transplantaciji. Zato se u vezi sa takvim medicinskim tretmanima ne može govoriti o jednakoj i pravičnoj dodeli dobara i pristupa zdravstvenoj zaštiti. Alternativne mogućnosti su, zbog brige o ljudskim pravima, za sada napuštene. S druge strane, evropska pravna rešenja za prevazilaženje problema nedostatka organa stvorila su novi, snažan monopol države i obavezu dostizanja pravičnog i nepristrasnog pristupa organima, njihovoj distribuciji 
i dodeli. Prema tome, ono što je preostalo jeste novo pravo u okviru prava na zdravlje, pravo na pristup transplantaciji, koje je nastalo kao posledica distribucije i dodele organa u javnom domenu.

Ključne reči: pravo na zdravlje, pravo na zdravstvenu zaštitu, dodela organa, donacija organa, transplantacija, nedostatak organa, biomedicina, bioetika, kadaver, mađarsko zdravstveno pravo.

Dostavljeno Redakciji: 1. novembra 2014. god.

Prihvaćeno za objavljivanje: 9. decembra 2014. god. 